\title{
Anti-tumor necrosis factor- $\alpha$ antibody treatment reduces pulmonary inflammation and methacholine hyper-responsiveness in a murine asthma model induced by house dust
}

\author{
J. Kim, L. McKinley, S. Natarajan, G.L. Bolgos, J. Siddiqui, S. Copeland and D. G. Remick
}

Department of Pathology, University of Michigan Medical School, Ann Arbor, MI, USA

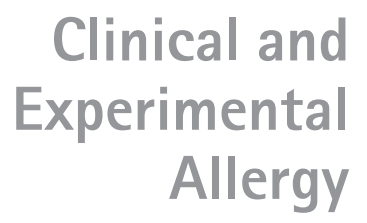

Correspondence:

Jiyoun Kim, Department of Pathology, University of Michigan Medical School, M2210 Med Sci I, 1301 Catherine Road, Ann Arbor, MI 48109-0602, USA.

E-mail: jiyoukim@umich.edu

\begin{abstract}
Summary
Background/Aims Recent studies documented that sensitization and exposure to cockroach allergens significantly increase children's asthma morbidity as well as severity, especially among inner city children. TNF- $\alpha$ has been postulated to be a critical mediator directly contributing to the bronchopulmonary inflammation and airway hyper-responsiveness in asthma. This study investigated whether an anti-TNF- $\alpha$ antibody would inhibit pulmonary inflammation and methacholine (Mch) hyper-responsiveness in a mouse model of asthma induced by a house dust extract containing both endotoxin and cockroach allergens.

Methods A house dust sample was extracted with phosphate-buffered saline and then used for immunization and two additional pulmonary challenges of BALB/c mice. Mice were treated with an intravenous injection of anti-TNF- $\alpha$ antibody or control antibody $1 \mathrm{~h}$ before each pulmonary challenge.

Results In a kinetic study, TNF- $\alpha$ levels within the bronchoalveolar lavage (BAL) fluid increased quickly peaking at $2 \mathrm{~h}$ while BAL levels of IL-4, IL-5, and IL-13 peaked at later time-points. Mch hyper-responsiveness was measured $24 \mathrm{~h}$ after the last challenge, and mice were killed $24 \mathrm{~h}$ later. TNF inhibition resulted in an augmentation of these Th2 cytokines. However, the allergic pulmonary inflammation was significantly reduced by anti-TNF- $\alpha$ antibody treatment as demonstrated by a substantial reduction in the number of BAL eosinophils, lymphocytes, macrophages, and neutrophils compared with rat IgG-treated mice. Mch hyper-responsiveness was also significantly reduced in anti-TNF- $\alpha$ antibody-treated mice and the pulmonary histology was also significantly improved. Inhibition of TNF significantly reduced eotaxin levels within the lung, suggesting a potential mechanism for the beneficial effects.These data indicate that anti-TNF- $\alpha$ antibody can reduce the inflammation and pathophysiology of asthma in a murine model of asthma induced by a house dust extract.
\end{abstract}

Keywords antibodies, chemokines, cytokines, eosinophils, lipopolysaccharide

Submitted 6 January 2005; revised 2 September 2005; accepted 17 October 2005

\section{Introduction}

Asthma is a complicated chronic inflammatory disease of the airways characterized by reversible airway obstruction, inflammatory mediator production, and airways hyper- responsiveness (AHR) [1]. Following exposure to allergens, numerous inflammatory cells and structural cells are activated such as macrophages, eosinophils, lymphocytes, and epithelial cells [1]. Upon activation, several inflammatory changes in the airways are triggered with the subsequent release of a wide variety of immunomodulator molecules into the airway [2]. Asthma is known as a T helper type 2 (Th2) disease with a specific cytokine profile including IL-4, IL-5, and IL-13 [3]. However, recent publications suggested that other cytokines categorized as $\mathrm{T}$ helper type 1 are also associated with asthmatic pulmonary inflammation in animals as well as in humans [4, 5]. TNF- $\alpha$, a potent pro-inflammatory mediator, plays various roles in the immunoregulation of asthma such as alteration of bronchial hyper-responsiveness [6], airway infiltration of neutrophils [7], activation of airway smooth muscle [8], activation of myofibroblasts [9], and changes in vascular permeability [10] including up-regulation of adhesion molecules such as E-selection, vascular cell adhesion molecule-1 and intercellular adhesion molecule-1 [11, 12]. In addition, TNF- $\alpha$ plays an 
important role in recruitment and activation of airway eosinophils [7, 13]. It has been documented that TNF- $\alpha$ expression within the airways of asthmatics is significantly increased in human subjects [14]. TNF- $\alpha$ is produced by various cell types in response to allergic pulmonary inflammation including mast cells, macrophages, neutrophils, eosinophils, and epithelial cells [2, 6].

In previous studies, we have developed a murine model of allergic asthma which shows methacholine (Mch) hyper-responsiveness, bronchopulmonary recruitment of inflammatory cells, and pulmonary expression of chemokines following house dust extract immunization and challenge $[15,16]$. This murine model was specifically developed following a landmark study that documented a strong correlation between sensitization to cockroach allergens and symptoms among asthmatic children in inner cities [17]. The model is based upon the use of house dust extracts containing high levels of cockroach allergens as well as endotoxin. This model of asthma-like pulmonary inflammation demonstrates recruitment of neutrophils, lymphocytes, and eosinophils into the lung, as well as Mch hyper-reactivity, and production of typical pro- inflammatory cytokines implicated in the pathogenesis of asthma. This unique model may be exploited further to examine therapeutic modalities to treat asthma. In the present study, we sought to determine whether a treatment option for acute asthma, such as neutralization of TNF- $\alpha$ would prevent an asthmatic response using this model. To examine this, animals were treated with the anti-TNF- $\alpha$ antibody before the onset of an asthmatic response, to investigate the role of TNF- $\alpha$ in pulmonary infiltration of inflammatory cells and bronchopulmonary hyper-responsiveness.

\section{Materials and methods}

\section{Animals}

Female BALB/c mice (18-20g) were purchased from Harlan Sprague Dawley Inc. (Indianapolis, IN, USA) and maintained under standard laboratory conditions. The mice were housed in a temperature-controlled room with a 12-h dark/light cycle and allowed food and water ad libitum. All experiments described below were performed in accordance with the National Institutes of Health guidelines, and approved by the University of Michigan Animal Use Committee.

\section{Sensitization and airway challenge}

The household dust used for all sensitizations and airway challenges was collected from a house in Detroit, MI as previously reported [16]. Briefly, a total of $4.3 \mathrm{~g}$ of dust was collected and resuspended with $30 \mathrm{~mL}$ of sterile phosphate-buffered saline (PBS) to allow aqueous extrac- tion. The collected supernatant was assayed for six different indoor allergens and three different outdoor allergens by ELISA. Our house dust extract contained very high concentrations of cockroach allergens $(378 \mathrm{U} / \mathrm{mL}$ of Bla g 1 and $6249 \mathrm{ng} / \mathrm{mL}$ of Bla g 2), and contained extremely low levels of four indoor allergens (dust mite Der p 1 and Der f 1, dog Can f 1 and cat Fel d 1) and three outdoor allergens (ragweed, mould, and grass). In addition to these allergens, our house dust extract contains $270 \mathrm{pg} / \mathrm{mL}$ of endotoxin. The house dust extract was diluted $1: 10$ for all experiments.

We used our previously described model of asthma [16] to induce the response. Mice were sensitized with an intraperitoneal $(100 \mu \mathrm{L})$ injection of house dust extract mixed 1:1 with an adjuvant (TiterMax Gold, CytRx, Norcross, GA, USA) on day 0 . On days 14 and 21, mice were given pulmonary challenges of $50 \mu \mathrm{L}$ of house dust extract while under isoflurane anaesthesia (Aerrane ${ }^{\circledR}$, Baxter, Deerfield, IL, USA). Hyper-responsiveness to Mch was measured on day 22, $24 \mathrm{~h}$ after the last pulmonary challenge. Mice were sacrificed $48 \mathrm{~h}$ after the last challenge (day 23). For one set of experiments, groups of mice were sacrificed at multiple time-points after the last pulmonary challenge to closely define the production of inflammatory mediators within the lung.

\section{Anti-TNF- $\alpha$ antibody treatment}

Neutralizing rat anti-mouse TNF- $\alpha$ monoclonal antibody (mAb) was used to block TNF- $\alpha$ bioactivity in HDEsensitized and challenged BALB/c mice. On day 14 and 21 , the immunized mice were treated with $10 \mu \mathrm{g}$ rat antimurine TNF- $\alpha$ mAb (Biosource International Inc., Camarillo, CA, USA) or $10 \mu \mathrm{g}$ rat IgG (Jackson ImmunoResearch Laboratories, West Grove, PA, USA) by intravenous (iv) injection $1 \mathrm{~h}$ before the pulmonary challenge. This dose of anti-TNF- $\alpha$ antibody has been used successfully to neutralize TNF activity in vivo [18] although it is possible that higher doses would have been even more efficacious.

\section{Measurement of methacholine hyper-responsiveness}

Whole body plethysmography (Buxco, Troy, NY, USA) was used to measure airway hyper-responsiveness (AHR) in response to increasing doses of aerosolized acetyl $\beta$ methylcholine (Sigma, St Louis, MO, USA) in unrestrained and conscious mice as previously reported [16]. Changes in early expiration because of bronchoconstriction will alter the waveform of the box pressure-time and can be quantified. These quantified alterations are expressed as enhanced pause $\left(P_{\mathrm{enh}}\right)$ as a main indicator of airway obstruction. $P_{\text {enh }}$ is strongly correlated with the airway resistance of the animal [19]. Either aerosolized PBS or Mch in increasing doses $(6,12,25$, and $50 \mathrm{mg} / \mathrm{mL})$ was nebulized through the inlet of the main chamber for 
$2 \mathrm{~min}$, and the response to each dose was subsequently measured for $5 \mathrm{~min}$. The average $P_{\mathrm{enh}}$ for $5 \mathrm{~min}$ was used to compare the results among experimental groups.

\section{Peripheral blood analysis}

For blood characterization, $20 \mu \mathrm{L}$ of EDTA (Sigma) anticoagulated blood was collected from the tail $48 \mathrm{~h}$ after the second airway challenge from mice anaesthetized with ketamine and xylazine solutions $(87 \mu \mathrm{g} / \mathrm{g}$ Ketamine plus $13 \mu \mathrm{g} / \mathrm{g}$ Xylazine, Ketaset ${ }^{\mathbb{R}}$; Fort Dodge Laboratories Inc., Fort Dodge, IA, USA. Rompun ${ }^{\circledR}$; Bayer Corporeation, Shawnee Mission, KS, USA). A Hemavet Mascot Multispecies Hematology System Counter 1500R (CDC Technologies Inc., Oxford, CT, USA) was used for a complete blood count [20]. Blood was also collected from the retroorbital venous plexus into tubes containing $50 \mathrm{U}$ of porcine derived heparin (Elkins-Sinn Inc., Cherry Hill, NJ, USA) before sacrifice. Plasma was collected by centrifugation $(600 \times g, 5 \mathrm{~min})$ and stored at $-20^{\circ} \mathrm{C}$ for later chemokine and cytokine analyses.

\section{Bronchoalveolar lavage fluid}

After blood collection, mice were euthanized by cervical dislocation. For the BAL, the trachea was exposed and intubated with a polyethylene catheter. BAL fluid was collected by washing with two separate aliquots of $1 \mathrm{~mL}$ of Hanks' Balanced Salt Solution (HBSS, Gibco-BRL, Grand Island, NY, USA) through the trachea. The first wash was centrifuged and the BAL supernatant stored for cytokine and chemokine analysis. The second wash was centrifuged, and the cell pellet from the first wash was pooled with the cell pellet from the second. A total cell count was obtained by using a Coulter counter model ZF (Coulter Electronics Inc., Hialeah, FL, USA). For differential counting, cells were prepared in a cytospin apparatus. Prepared cytospin slides were stained with Diff-Quick (Baxter, Detroit, MI, USA) and cell differentials were performed after counting 300 cells.

\section{Histopathology}

Immediately after collecting the BAL, the left lung and trachea from each mouse was removed, fixed in 10\% buffered formalin, and processed for routine histology in paraffın. Tissue sections were stained with haematoxylin/ eosin and then examined under light microscopy by a board-certified pathologist (DGR). Digital images were taken of each of the lung from each animal and the entire histologic section on the glass slide was selected and areas quantified using the NIH ImageJ software. The outline of each region of interest was traced and areas in square pixels are calculated using the measure feature. Areas of inflammation were calculated by measuring the peribronchial and perivascular areas occupied by inflammatory cells and subtracting the area of the inner null space. For each section, the sum of these areas of inflammation is expressed as the percentage of the total area of the section.

\section{Preparation of lung homogenates}

After the BAL fluid was collected, the right lung was removed and immediately placed in $3 \mathrm{~mL}$ of ice-cold homogenization buffer (0.05\% Triton X-100 (Sigma) in PBS). Three, 10-s rounds of homogenization and sonication were followed by centrifugation $(15000 \times g$ for $15 \mathrm{~min}$ at $4^{\circ} \mathrm{C}$ ). This supernatant was used directly in the eotaxin ELISA. For the myeloperoxidase assay, the supernatant was mixed $1: 1$ with MPO assay buffer and added to 96 -well plate $(20 \mu \mathrm{L})$. Assay buffer $(200 \mu \mathrm{L})$ containing $100 \mathrm{~mm}$ potassium phosphate, $0.834 \mathrm{~mL} o$-dianisidine $\mathrm{HCl}$ ( $10 \mathrm{mg} / \mathrm{mL}$, Sigma) and $0.083 \mathrm{~mL} 0.3 \% \mathrm{H}_{2} \mathrm{O}_{2}$ in $50 \mathrm{~mL}$ deionized water was added immediately before reading. The reaction was assayed in a Biotek microplate reader (Bio-Tek Instruments, Inc., Winoski, VT, USA) every $10 \mathrm{~s}$ at $465 \mathrm{~nm}$. The data were expressed as the slope of change in optical density over $100 \mathrm{~s}$. It should be noted that our myeloperoxidase assay of lung homogenates measured peroxidase from neutrophils and eosinophils [21].

\section{Cytokine and chemokine analysis}

All chemokine and cytokine measurements were performed simultaneously to reduce errors because of interassay variation. TNF- $\alpha$ and eotaxin were measured by ELISA using matched antibody pairs (RED Systems Inc., Minneapolis, MN, USA) as previously described [22]. For the lung homogenate eotaxin ELISA, the standard was diluted in homogenate fluid from normal lungs in order to keep a similar protein background in both samples and standard. IL-4, IL-5, and IL-13 were measured by a multiplex, microarray immunoassay developed in our laboratory [23]. These cytokines were measured in this format so that we would be able to measure all three of the cytokines with the small amount of remaining sample.

\section{Statistical analyses}

Mean \pm standard error of the mean was used for summary statistics in all figures. Differences between all treatment groups were compared by Anova. A Tukey's test for pair-wise comparisons was performed when the overall $F$-value was statistically significant $(P<0.05)$.

\section{Results}

Kinetics of bronchoalveolar lavage TNF- $\alpha$ after immunization and challenge

To investigate the role of TNF- $\alpha$ in this murine model of asthma, BALB/c mice were immunized and intratracheally 


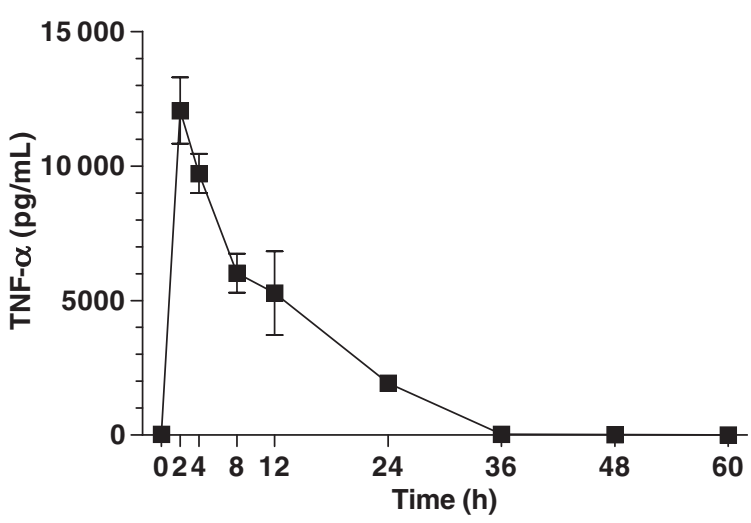

Fig. 1. Kinetics of TNF- $\alpha$ expression in mouse lung lavage from house dust extract sensitized and challenged BALB/c mice. Groups of mice were sacrificed and BAL was collected at the indicated time-points after the last challenge. TNF- $\alpha$ concentrations were determined using matched antibody pairs via ELISA. Values represent mean \pm SEM with $n=4$ for each group.

challenged with a house dust extract containing high levels of cockroach allergens as well as endotoxin. Groups of mice were immunized on day 0 and received pulmonary challenges on day 14 and 21. After the last challenge (day 21), mice were sacrificed at time intervals from 2 to $60 \mathrm{~h}$ and BAL fluid was collected. A group of mice were sacrificed at $0 \mathrm{~h}$, that is on day 21 but before the second pulmonary challenge. The concentration of TNF- $\alpha$ in lung lavage fluid was below detection limits immediately before the second pulmonary challenge. On day $21,2 \mathrm{~h}$ after the last intratracheal challenge, TNF levels in the lavage peaked and then declined (Fig. 1). Pulmonary expression of TNF- $\alpha$ declined dramatically within $24 \mathrm{~h}$ of the last challenge. These results are similar to other reports where TNF peaks rapidly in the BAL fluid after pulmonary challenge [24] and provide a strong rationale for targeting TNF- $\alpha$.

Kinetics of bronchoalveolar lavage interleukin-4, -5, and -13 after immunization and challenge

As the Th2 cytokines IL-4, IL-5, and IL-13 have been implicated in the pathogenesis of asthma [25],we measured their levels in the BAL fluid after the last pulmonary challenge (Fig. 2). Similar to TNF, none of these cytokines were detectable at time 0 , i.e. immediately before the last pulmonary challenge. Each of these cytokines became elevated, although the kinetics were slightly delayed relative to the production of TNF observed in Fig. 1. The local levels of these cytokines also persisted longer, with detectable levels still present beyond $24 \mathrm{~h}$ after the last pulmonary challenge.

\section{Anti-TNF- $\alpha$ antibody increases bronchoalveolar lavage levels of T helper type 2 cytokines}

BAL samples from the 48-h time-point were examined for Th2 cytokine levels to determine if the levels would be
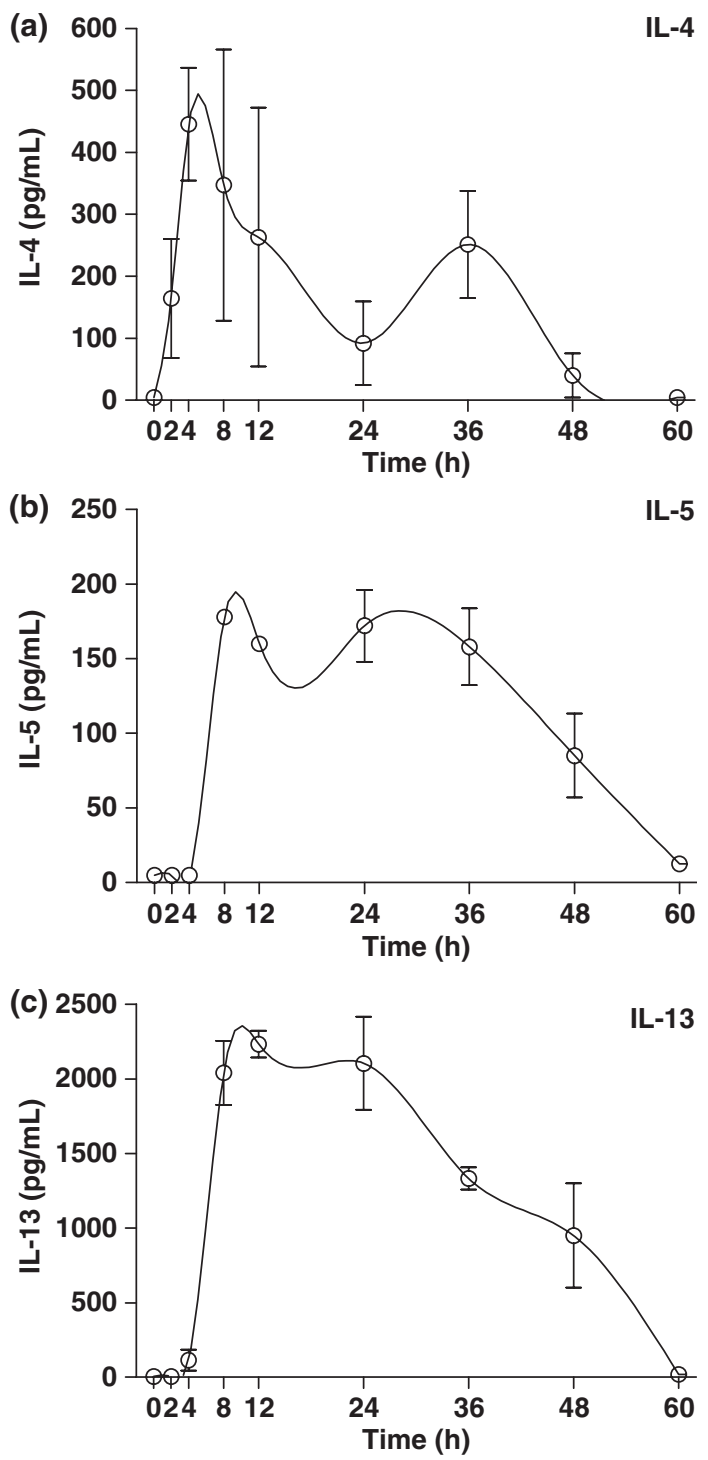

Fig. 2. Kinetics of IL-4, IL-5, and IL-13 expression in mouse lung lavage from house dust extract sensitized and challenged BALB/c mice. Each group of mice was sacrificed and BAL was collected after the last challenge at the indicated time-points. The concentrations of each cytokine were measured by a multiplex, microarray immunoassay developed in our laboratory. Values represent mean \pm SEM with $n=4$ for each group.

modulated by anti-TNF- $\alpha$ antibody therapy. Surprisingly, each of the Th2 cytokines was significantly elevated when TNF was inhibited (Fig. 3). We next examined whether the pulmonary inflammation would be altered by blockade of TNF.

\section{Anti-TNF- $\alpha$ reduces antibody pulmonary recruitment of inflammatory cells}

TNF was inhibited by the iv injection of a rat anti-mouse TNF- $\alpha$ antibody $1 \mathrm{~h}$ before both of the intratracheal challenges and mice were sacrificed $48 \mathrm{~h}$ after the last 

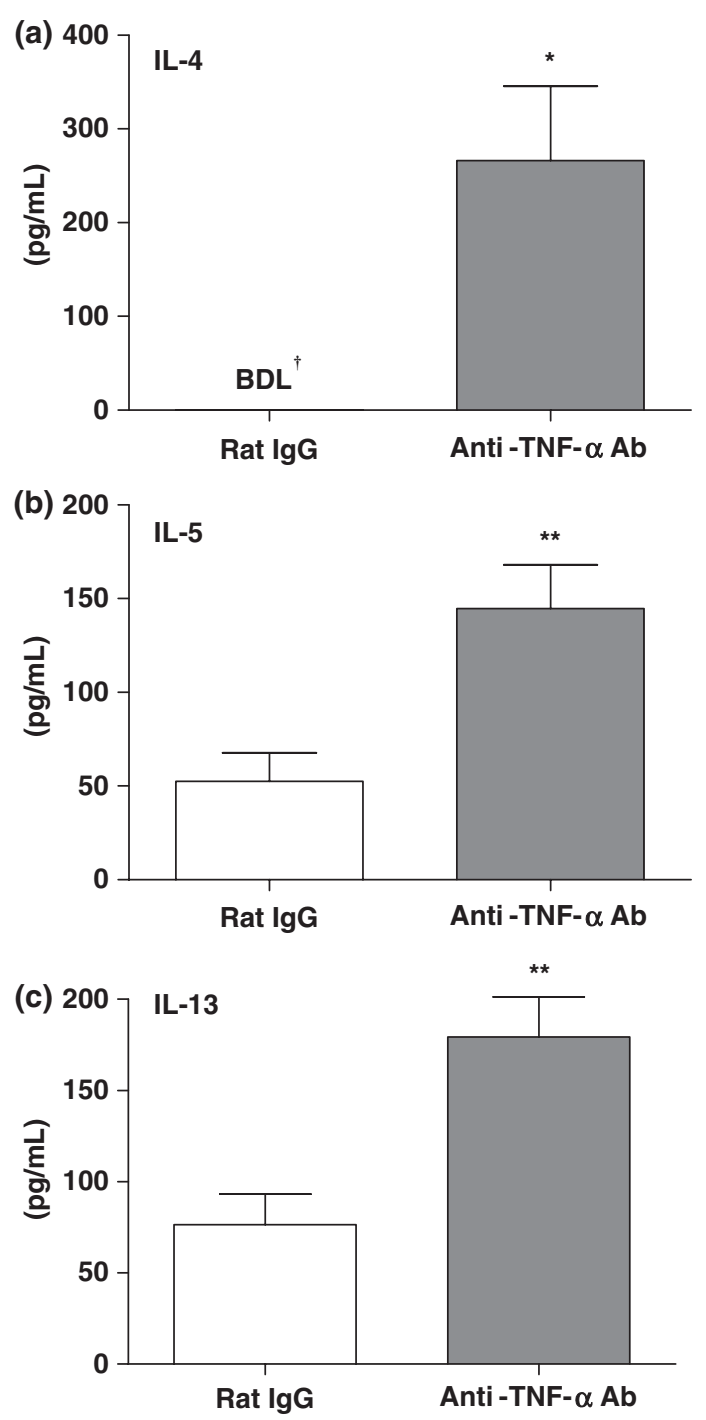

Fig. 3. Increased expression of IL-4, IL-5, and IL-13 in BAL after antiTNF- $\alpha$ Ab treatment. Mice were treated with an intravenous (iv) injection of anti-TNF- $\alpha$ Ab or control rat IgG and BAL collected at $48 \mathrm{~h}$ after the last challenge. For each of these Th2 cytokines, inhibition of TNF increased the BAL concentrations. Values represent mean \pm SEM with $n=6-8$ for each group. ${ }^{\dagger}$ Below detectable level.

challenge. As shown in Fig. 4, the numbers of inflammatory cells in BAL including total leucocytes, eosinophils, lymphocytes, and macrophages in anti-TNF- $\alpha$ antibodytreated mice were significantly lower than those in the control rat IgG-treated mice. Additionally, the number of neutrophils recovered from the BAL was significantly reduced (Fig. 5). The effect of antibody treatment on the pulmonary recruitment of neutrophils in this model was further evaluated by measurement of pulmonary myeloperoxidase activity (Fig. 5). Using the myeloperoxidase assay, the neutrophil activity within the lung tissue was significantly decreased in anti-TNF- $\alpha$ antibody-treated mice $(P<0.01)$ compared with the control, rat IgGtreated mice. Even though it is important to distinguish between eosinophils and neutrophils in the asthmatic inflammatory reaction [21], our myeloperoxidase assay of lung homogenates measured peroxidase from neutrophils and eosinophils.

Inflammatory cell recruitment into the lungs of antiTNF- $\alpha$ antibody-treated mice was further investigated by histopathological studies (Figs 6 and 7). Mice were immunized and challenged according to the standard protocol, and separate groups treated with control antibody or anti-TNF- $\alpha$ antibody. Lungs were harvested and processed for histology $48 \mathrm{~h}$ after the last pulmonary challenge and BAL collection. Control antibody-treated mice (Fig. 6a) had a significant influx of inflammatory cells that included lymphocytes and eosinophils. These cells were located in both the peribronchial and perivascular spaces. The infiltration of inflammatory cells was significantly reduced by anti-TNF- $\alpha$ antibody treatment and was, in fact, nearly similar to normal mouse histology (Fig. 6b). It was difficult to discern any significant inflammation in some of the anti-TNF- $\alpha$ antibody-treated mice. Pulmonary infiltration of inflammatory cells was further confirmed by computer-aided morphometry of the histologic sections. The total area of occupied by inflammation in the anti-TNF- $\alpha$ antibody-treated mice was significantly lower than the rat IgG-treated mice (Fig. 7).

We then ascertained whether the numbers of circulating inflammatory cells were affected by iv administration of anti-TNF- $\alpha$ antibody. Immunized and challenged mice were sacrificed $48 \mathrm{~h}$ after the last intratracheal challenge and peripheral blood was harvested for complete blood counting. Interestingly, the total number of peripheral white blood cells, lymphocytes, and monocytes in the anti-TNF- $\alpha$ antibody-treated mice were higher than in mice treated with rat IgG (data not shown), indicating that the anti-TNF- $\alpha$ antibody treatment did not have a non-specific toxic effect. A similar result has been observed in patients with rheumatoid arthritis who are treated with antibodies to TNF because they also have a leucocytosis [26].

\section{Anti-TNF- $\alpha$ antibody improves methacholine hyper- responsiveness}

An increase in AHR to Mch challenge has been considered a diagnostic sign in models of allergic asthma [27]. To confirm the beneficial effects of the anti-TNF- $\alpha$ antibody treatment, mice were evaluated by measuring $P_{\text {enh }}$ via whole body plethysmography. Mch hyper-responsiveness was measured $24 \mathrm{~h}$ after the last pulmonary challenge. As shown in Fig. 8, bronchopulmonary hyper-responsiveness in response to increasing doses of Mch in the anti-TNF- $\alpha$ antibody-treated and rat IgG-treated mice increased in a dose-dependent manner. AHR in anti-TNF- $\alpha$-treated mice was significantly reduced when compared with control IgG-treated mice $(P=0.03$ and 0.02 at $25 \mathrm{mg} / \mathrm{mL}$ and $50 \mathrm{mg} / \mathrm{mL}$ Mch challenge, respectively). 

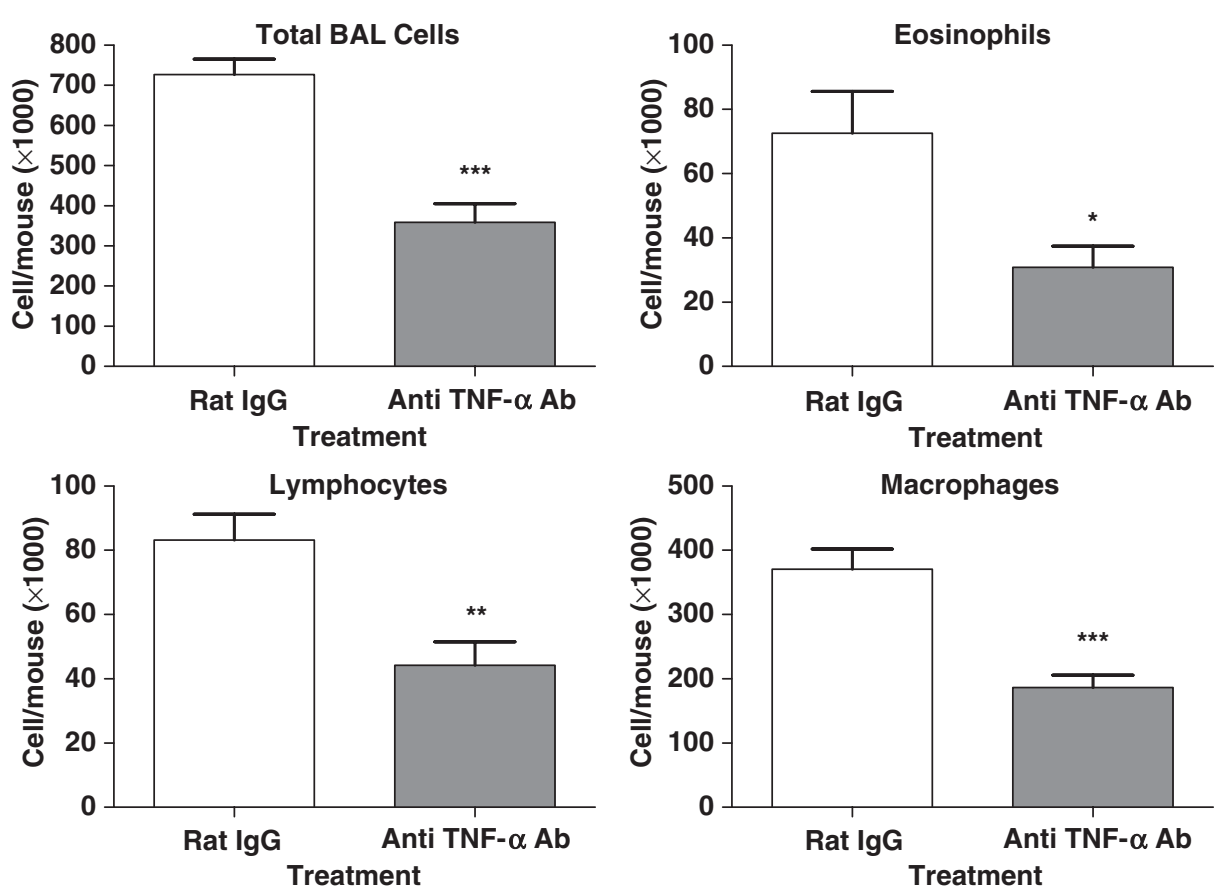

Fig. 4. Antibody treatment decreases BAL inflammatory cell infiltration. Mice were treated with anti-TNF- $\alpha$ antibody (10 $\mu \mathrm{g}$ per mouse) or rat IgG $1 \mathrm{~h}$ before each pulmonary challenge and BAL cells determined $48 \mathrm{~h}$ after the last intratracheal challenge. Values represent mean \pm SEM with $n=8$ for each group. ${ }^{*} P<0.05,{ }^{* *} P<0.01$, or ${ }^{* * *} P<0.001$ when compared with rat IgG-treated mice.

\section{Effects of anti-TNF- $\alpha$ antibody treatment on pulmonary expression of chemokines}

We had previously demonstrated that inhibition of eotaxin would reduce pulmonary inflammation in this murine model of asthma [16]. Several investigators have published that TNF will induce the expression of eotaxin in cells present in normal lungs such as airway smooth muscle cells [28] or bronchial epithelial cells [29, 30]. If the anti-TNF- $\alpha$ antibody decreased eotaxin levels it would suggest a potential mechanism of how TNF reduced the pulmonary inflammation. For these studies, we examined the eotaxin levels within the blood, BAL and lung homogenates $48 \mathrm{~h}$ after the last pulmonary challenge. The BAL levels of eotaxin were below detection limits and there was no difference in the blood eotaxin levels between anti-TNF- $\alpha$ antibody and control rat IgG mice. However, blockade of TNF did result in a significant reduction in the levels of eotaxin in the lung homogenates (Fig. 9).

\section{Discussion}

Asthma is one of the commonest illnesses in western countries and affects $8-10 \%$ of children and 3-5\% of the adult population [31]. In the United States, approximately 17 million Americans suffer from asthma [32]. Among them, 4.8 million are children under the age of 18 [33]. The morbidity and mortality because of asthma have increased 75\% from 1980 to 1994 in the United States
[32] and the reasons for this recent increase have not been fully identified. Increased levels of indoor allergens including dust mite, cockroach, and pet dander represent some of possible reasons [34, 35]. Recent published studies have demonstrated that sensitization to cockroach allergens is strongly correlated with the increased asthma morbidity for both adults and children, especially children living in the inner cities of the United States $[17,36]$. Thus, it is of great interest to develop experimental murine models that demonstrate the principal aspects of asthma by using house dust containing high levels of cockroach allergens.

Pulmonary inflammation and structural changes in the airways induce AHR via the expression of inflammatory mediators including cytokines and chemokines (reviewed in [2]). These inflammatory mediators induce remodelling of asthmatic airways through the modification of the smooth muscle contractility, influx of inflammatory cells, vascular permeability, and mucus secretion [37-39]. Understanding the role of the cytokines and chemokines that modulate the pathophysiology of asthma is essential to the development of new interventions for the treatment of asthma.

TNF- $\alpha$, a multifunctional pro-inflammatory cytokine, has been postulated to play an important role in the pathogenesis of asthma $[9,40,41]$. Various in vivo studies have shown involvement of TNF- $\alpha$ in asthma by alteration of the contractile properties of the airway smooth muscle [8], regulating AHR [6, 42], and neutrophilia [6]. TNF- $\alpha$ is 

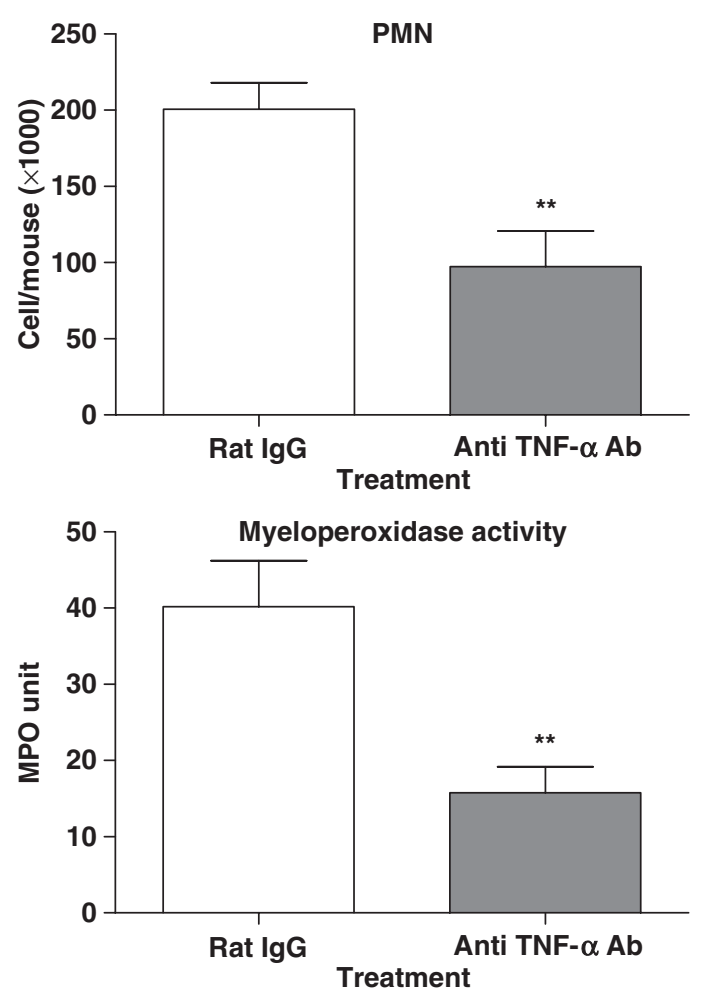

Fig. 5. Anti-TNF- $\alpha$ antibody treatment decreases the number of neutrophils in lung lavage and pulmonary myeloperoxidase activity. After the BAL fluid was collected, the right lung was removed and immediately processed for the assay. Inhibition of TNF decreased both the number of recruited neutrophils as well as the myeloperoxidase activity of the lung. Values represent mean \pm SEM with $n=8$ for each group. ${ }^{* *} P<0.01$ when compared with rat IgG-treated mice.

overexpressed in blood and BAL of asthma patients [14, 43]. TNF has been found by immunostaining to be present in the bronchial biopsies from asthmatic patients [44, 45]. This expression of pro-inflammatory cytokines is augmented by environmental mediators such as endotoxin that are frequently present in house dust [46]. Further, alveolar macrophages from wheezy infants show increased spontaneous release of TNF [47].

We previously reported a murine model of asthma-like bronchopulmonary inflammation induced by a house dust extract that contained high levels of cockroach allergens and moderate levels of lipopolysaccharide $[15,16]$. This murine model of asthma simulates many features of human asthma including exacerbation of AHR, pulmonary infiltration of inflammatory cells, and increased recruitment of inflammatory cells and chemokines in BAL.

In this study, we investigated the effects of anti-TNF- $\alpha$ antibody treatment on the features demonstrated in a murine model of asthma in an effort to expand the current understanding of the mechanism of AHR and pulmonary inflammation. The role of TNF- $\alpha$ in asthma remains controversial with conflicting results in the literature. In

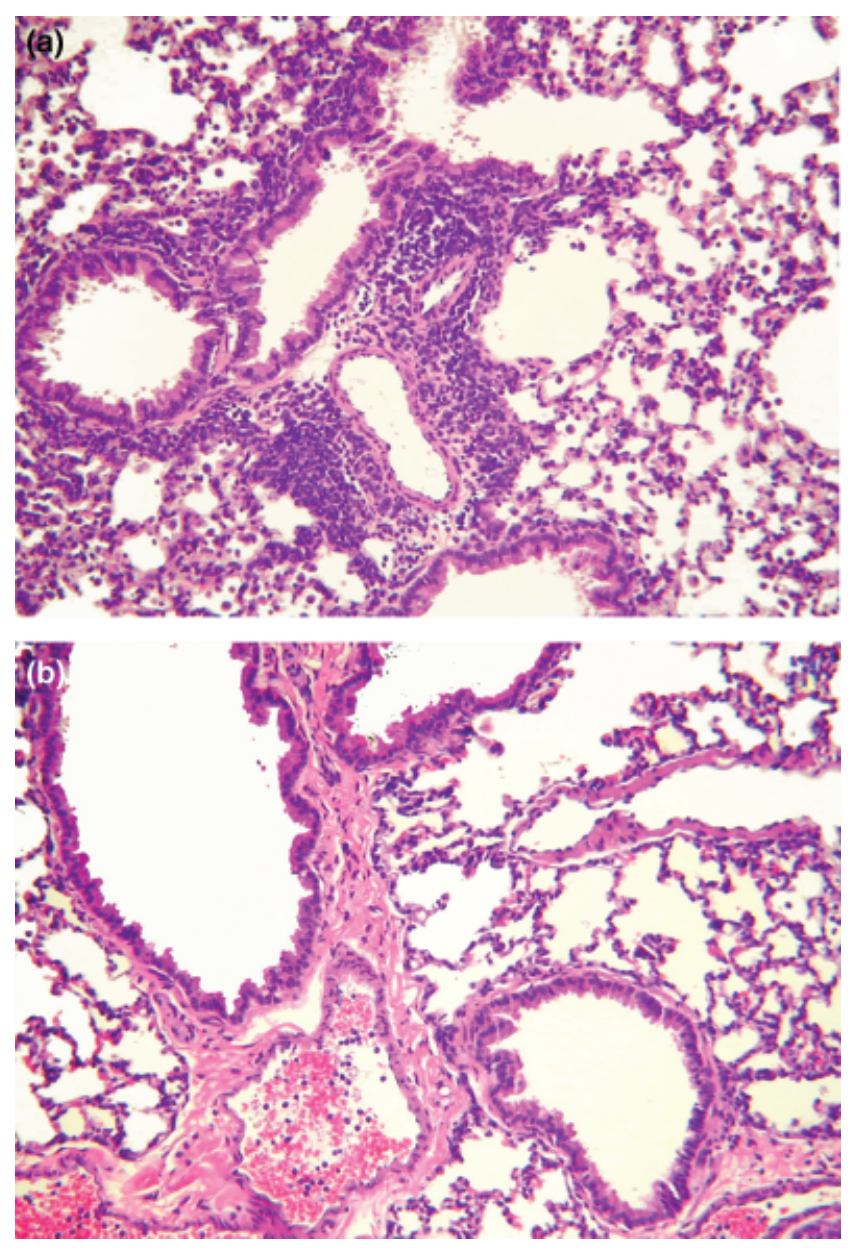

Fig. 6. Histology of lung tissue in anti-TNF- $\alpha$ antibody and rat IgGtreated mouse after immunized and challenged with house dust extract. Lungs were harvested $48 \mathrm{~h}$ after the last pulmonary challenge and after bronchoalveolar lavage (BAL) fluid was harvested. (a) Representative histology from a rat IgG-treated mouse with a marked peribronchial and perivascular infiltration of eosinophils and lymphocytes. (b) Representative histology from an anti-TNF- $\alpha$ antibody-treated mouse with essentially normal histology. Both pictures same magnification.

an ovalbumin (OVA) model of murine asthma, Rudmann et al. [48] found that TNF receptor knockout mice (lacking both TNF receptors) had pulmonary inflammation comparable to wild-type mice. However, Broide et al. [49]found decreased pulmonary inflammation in the TNF receptor knockout mice also while using an OVA model. Blockade of TNF activity has been performed using either antibodies or TNF soluble receptors. In the OVA model, some groups have shown that blocking TNF does not alter cellular recruitment $[48,50]$ while others have demonstrated a reduction in the pulmonary recruitment of inflammatory cells [51-53]. In a model of occupational asthma, blockade of TNF had a beneficial effect [54]. Our data shows a strong protective effect when TNF is inhibited in our model of murine asthma. A strength of the present report lies in the model used to test the hypothesis 


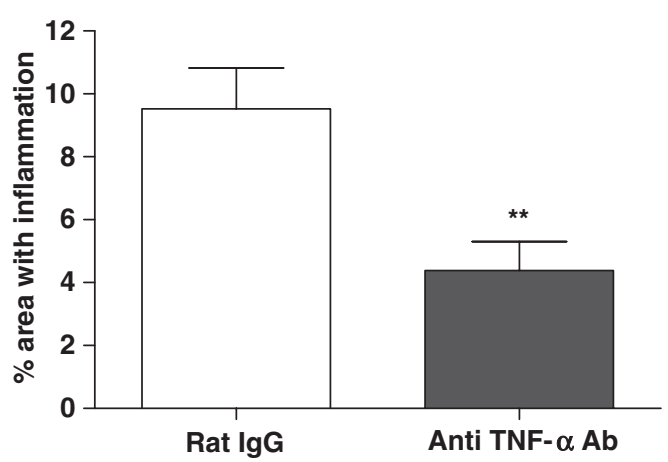

Fig. 7. Anti-TNF- $\alpha$ antibody treatment reduced pulmonary inflammation. Digital images were taken from lungs harvested as described in Fig. 6 , the entire histologic section on the glass slide was selected and areas are quantified using the NIH ImageJ software. The area of inflammation was calculated by measuring the peribronchial and perivascular areas occupied by inflammatory cells and subtracting the area of the inner null space. The data are expressed as the percentage of the total lung area occupied by inflammation. ${ }^{* *} P<0.01$ when compared with rat IgGtreated mice.

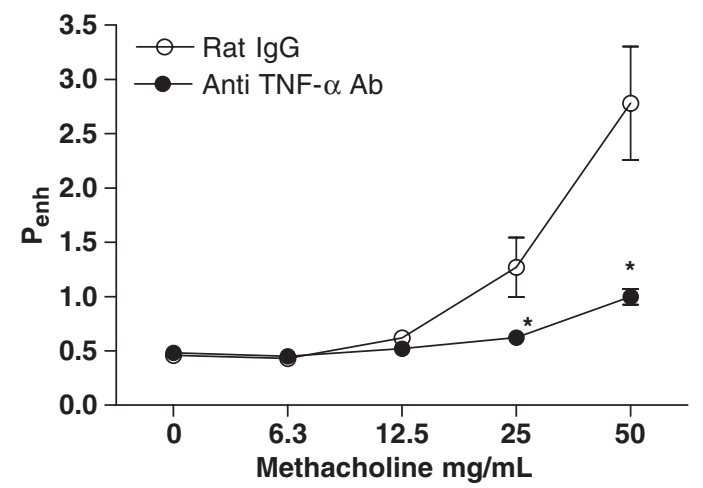

Fig. 8. Airway hyper-responsiveness (AHR) reduced in anti-TNF- $\alpha$ Abtreated mice. $P_{\text {enh }}$ values were obtained from mice $24 \mathrm{~h}$ after the last challenge in response to nebulized methacholine (Mch) via whole body plethysmography. The data are expressed as the mean \pm SEM of $P_{\text {enh }}$ values $(n=6-8)$. ${ }^{*} P<0.05$ when compared with rat IgG-treated group.

that blocking TNF will improve outcome. As the model is based on house dust actually obtained from the homes of children with asthma, the results discussed in this report may be more indicative of the role of TNF in human disease.

In addition to measuring TNF, we also measured the Th2 cytokines IL-4, IL-5, and IL-13. In the kinetics studies, the cytokines peaked at later time-point compared to TNF with IL-4 peaking at $4 \mathrm{~h}$, IL- 5 at $8 \mathrm{~h}$, and IL-13 between 12 and $24 \mathrm{~h}$. These chemokines have been reported to be critical in the host response to allergic type inflammation [25]. In what might appear to be a paradoxical response, inhibition of TNF resulted in augmentation of these Th2 cytokines. However, as the data indicates, blocking TNF significantly reduced the inflammatory response. The increase in the Th2 cytokines may represent a compensatory response in attempt to increase the pulmonary

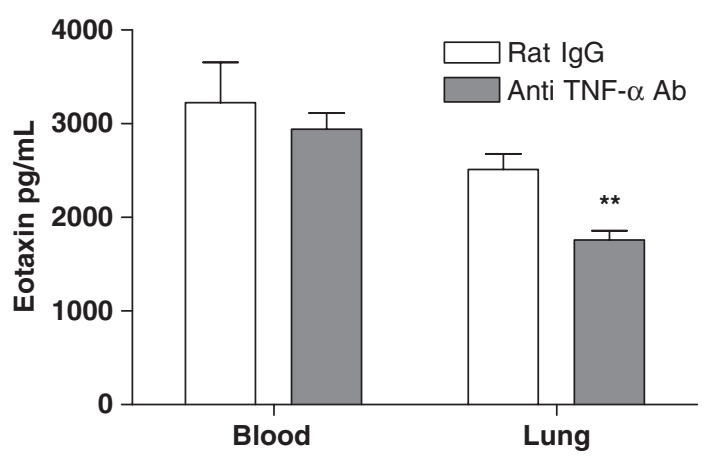

Fig. 9. Reduced levels of eotaxin in the lung of BALB/c mice treated with anti-TNF- $\alpha$ antibody. Chemokine levels were determined by ELISA in the blood and in the lung homogenate harvested at $48 \mathrm{~h}$ after the last intratracheal challenge. Values represent mean \pm standard error of the mean (SEM) with $n=6-8$ for each group. ${ }^{* *} P<0.01$ compared with rat IgG-treated mice.

inflammation. This has been observed with other cytokines, where an increase in local concentrations is observed in attempt to attain what the host perceives to be the appropriate inflammatory response $[55,56]$. In other words, the Th2 cytokines increase in attempt to increase the level of pulmonary inflammation, even though this was not successful. As an example, IL-4 has been shown to increase mast cell secretion of histamine and leucotrienes [57] so IL-4 levels may be increased to try and augment the recruitment of inflammatory cells.

The mechanism of the inhibition of TNF was also explored in this study by examining the regulation of eotaxin. Several investigators have documented the importance of the double cysteine (CC) chemokine eotaxin in the pathogenesis of asthma. Previous work has correlated the levels of eotaxin with pulmonary eosinophils in animal models $[1,58,59]$. The correlation of eotaxin with pulmonary inflammation has also been observed in humans [60]. A strong link exists between TNF and eotaxin because several investigators have demonstrated that TNF will increase eotaxin [61, 62]. There are several types of cells present in normal lung that may be stimulated with TNF to produce eotaxin. Included in this list are fibroblasts [63-65], airway smooth muscle cells [66], mesothelial cells [67], and airway epithelial cells [29, 30]. In one study, TNF was able to induce eotaxin production in fibroblasts, endothelial cells and epithelial cells [68]. Additionally, several studies have shown that numerous inflammatory mediators will synergize with TNF to induce eotaxin $[30,63,68]$. These previous studies provide a potential mechanism of how the blockade of TNF will reduce asthma-like pulmonary inflammation.

Blockade of TNF has already been used to treat human diseases of chronic inflammation. The synthesis and activity of TNF- $\alpha$ can be blocked by various ways including monoclonal antibodies to TNF- $\alpha$-soluble TNF receptors, and TNF- $\alpha$ converting enzyme inhibitor $[46,69,70]$. 
Currently an anti-TNF- $\alpha$ blocking antibody is being used to treat chronic inflammatory diseases including Crohn's disease, psoriatic arthritis, and rheumatoid arthritis [71]. The studies using TNF inhibitors for the treatment of rheumatoid arthritis extend back several years and the clinical results have been impressive [72]. These dramatic results with TNF inhibitors in human patients provide a strong rationale for their use in other chronic diseases such as asthma.

\section{Acknowledgements}

This work was supported in part by a grant from the National Institute of Environmental Health Sciences grant ES 09589 and the US Environmental Protection Agency grant R826710-01.

The Michigan Center for the Environment \&t Children's Health (MCECH) is a community-based participatory research initiative investigating the influence of environmental factors on childhood asthma. MCECH involves collaboration among the University of Michigan Schools of Public Health and Medicine, the Detroit Health Department, the Michigan Department of Agriculture, Plant and Pest Management Division, and nine community-based organizations in Detroit (Butzel Family Center, Community Health and Social Services Center - CHASS, Detroiters Working for Environmental Justice, Detroit Hispanic Development Corporation, Friends of Parkside, Kettering/ Butzel Health Initiative, Latino Family Services, United Community Housing Coalition and Warren/Conner Development Coalition), and Henry Ford Health System.

\section{References}

1 Rankin SM, Conroy DM, Williams TJ. Eotaxin and eosinophil recruitment: implications for human disease. Mol Med Today 2000; 6:20-7.

2 Barnes PJ, Chung KF, Page CP. Inflammatory mediators of asthma: an update. Pharmacol Rev 1998; 50:515-96.

3 Walker JK, Fong AM, Lawson BL et al. \{beta\}-Arrestin-2 regulates the development of allergic asthma. J Clin Invest 2003; 112:566-74.

4 Teran LM, Mochizuki M, Bartels J et al. Th1- and Th2-type cytokines regulate the expression and production of eotaxin and RANTES by human lung fibroblasts. Am J Respir Cell Mol Biol 1999; 20:777-86.

5 Garcia-Zepeda EA, Combadiere C, Rothenberg ME et al. Human monocyte chemoattractant protein (MCP)-4 is a novel CC chemokine with activities on monocytes, eosinophils, and basophils induced in allergic and nonallergic inflammation that signals through the CC chemokine receptors (CCR)-2 and -3. J Immunol 1996; 157:5613-26.

6 Thomas PS, Yates DH, Barnes PJ. Tumor necrosis factor-alpha increases airway responsiveness and sputum neutrophilia in normal human subjects. Am J Respir Crit Care Med 1995; 152:76-80.
7 Lukacs NW, Strieter RM, Chensue SW, Widmer M, Kunkel SL. TNF-alpha mediates recruitment of neutrophils and eosinophils during airway inflammation. J Immunol 1995; 154:5411-7.

8 Amrani Y, Chen H, Panettieri RA Jr. Activation of tumor necrosis factor receptor 1 in airway smooth muscle: a potential pathway that modulates bronchial hyper-responsiveness in asthma? Respir Res 2000; 1:49-53.

9 Thomas PS. Tumour necrosis factor-alpha: the role of this multifunctional cytokine in asthma. Immunol Cell Biol 2001; 79:132-40.

10 Hybertson BM, Jepson EK, Cho OJ, Clarke JH, Lee YM, Repine JE. TNF mediates lung leak, but not neutrophil accumulation, in lungs of rats given IL-1 intratracheally. Am J Respir Crit Care Med 1972; 155:1972-6.

11 Tosi MF, Stark JM, Smith CW, Hamedani A, Gruenert DC, Infeld MD. Induction of ICAM-1 expression on human airway epithelial cells by inflammatory cytokines: effects on neutrophil-epithelial cell adhesion. Am J Resp Cell Mol Biol 1992; 7:214-21.

12 Thornhill MH, Wellicome SM, Mahiouz DL, Lanchbury JS, KyanAung U, Haskard DO. Tumor necrosis factor combines with IL-4 or IFN-gamma to selectively enhance endothelial cell adhesiveness for $\mathrm{T}$ cells. The contribution of vascular cell adhesion molecule-1-dependent and -independent binding mechanisms. J Immunol 1991; 146:592-8.

13 Casale TB, Costa JJ, Galli SJ. TNF alpha is important in human lung allergic reactions. Am J Respir Cell Mol Biol 1996; 15:35-44.

14 Broide DH, Lotz M, Cuomo AJ, Coburn DA, Federman EC, Wasserman SI. Cytokines in symptomatic asthma airways. J Allergy Clin Immunol 1992; 89:958-67.

15 McKinley L, Kim J, Bolgos GL, Siddiqui J, Remick DG. Reproducibility of a novel model of murine asthma-like pulmonary inflammation. Clin Exp Immunol 2004; 136:224-31.

16 Kim J, Merry AC, Nemzek JA, Bolgos GL, Siddiqui J, Remick DG. Eotaxin represents the principal eosinophil chemoattractant in a novel murine asthma model induced by house dust containing cockroach allergens. J Immunol 2001; 167:2808-15.

17 Rosenstreich DL, Eggleston P, Kattan M et al. The role of cockroach allergy and exposure to cockroach allergen in causing morbidity among inner-city children with asthma [see comments]. New Engl J Med 1997; 336:1356-63.

18 Huang X, McClellan SA, Barrett RP, Hazlett LD. IL-18 contributes to host resistance against infection with Pseudomonas aeruginosa through induction of IFN-gamma production. J Immunol 2002; 168:5756-63.

19 Hamelmann E, Schwarze J, Takeda K et al. Noninvasive measurement of airway responsiveness in allergic mice using barometric plethysmography [see comments]. Am J Respir Crit Care Med 1997; 156:766-75.

20 Nemzek JA, Bolgos GL, Williams BA, Remick DG. Differences in normal values for murine white blood cell counts and other hematological parameters based on sampling site. Inflammation Res 2001; 50:523-7.

21 Schneider T, Issekutz AC. Quantitation of eosinophil and neutrophil infiltration into rat lung by specific assays for eosinophil peroxidase and myeloperoxidase. Application in a Brown Norway rat model of allergic pulmonary inflammation. $J$ Immunol Methods 1996; 198:1-14. 
22 Nemzek JA, Siddiqui J, Remick DG. Development and optimization of cytokine ELISAs using commercial antibody pairs. J Immunol Methods 2001; 255:149-57.

23 Knight PR, Sreekumar A, Siddiqui J et al. Development of a sensitive microarray immunoassay and comparison with standard enzyme-linked immunoassay for cytokine analysis. Shock 2004; 21:26-30.

24 Ohkawara Y, Lei XF, Stampfli MR, Marshall JS, Xing Z, Jordana M. Cytokine and eosinophil responses in the lung, peripheral blood, and bone marrow compartments in a murine model of allergen-induced airways inflammation. Am J Respir Cell Mol Biol 1997; 16:510-20.

25 Ngoc PL, Gold DR, Tzianabos A0, Weiss ST, Celedon JC. Cytokines, allergy, and asthma. Curr Opin Allergy Clin Immunol 2005; 5:161-6.

26 Elliott MJ, Maini RN, Feldmann M et al. Treatment of rheumatoid arthritis with chimeric monoclonal antibodies to tumor necrosis factor alpha. Arthritis Rheum 1993; 36:1681-90.

27 Wills-Karp M. Immunologic basis of antigen-induced airway hyperresponsiveness. Ann Rev Immunol 1999; 17:255-81.

28 Chung KF, Patel HJ, Fadlon EJ et al. Induction of eotaxin expression and release from human airway smooth muscle cells by IL-1beta and TNFalpha: effects of IL-10 and corticosteroids. Br J Pharmacol 1999; 127:1145-50.

29 Matsukura S, Stellato C, Plitt JR et al. Activation of eotaxin gene transcription by NF-kappa B and STAT6 in human airway epithelial cells. J Immunol 1999; 163:6876-83.

30 Fujisawa T, Kato Y, Atsuta J et al. Chemokine production by the BEAS-2B human bronchial epithelial cells: differential regulation of eotaxin, IL-8, and RANTES by TH2- and TH1-derived cytokines. J Allergy Clin Immunol 2000; 105:126-33.

31 Michel FB, Neukirch F, Bousquet J. L'asthme: un probleme mondial de sante publique. Bull Acad Nat Med 1995; 179:279-93; discussion 293-7.

32 anonymous. Forecasted state-specific estimates of self-reported asthma prevalence - United States, 1998. MMWR - Morbidity \& Mortality Weekly Report 1998; 47:1022-5.

33 Anonymous. Update: future directions for research on diseases of the lung. The American Thoracic Society. Am J Respir Crit Care Med 1998; 158:320-34.

34 Platts-Mills TA, Blumenthal K, Perzanowski M, Woodfolk JA. Determinants of clinical allergic disease. The relevance of indoor allergens to the increase in asthma. Am J Respir Crit Care Med 2000; 162:S128-33.

35 Eggleston PA, Rosenstreich D, Lynn H et al. Relationship of indoor allergen exposure to skin test sensitivity in inner-city children with asthma. J Allergy Clin Immunol 1998; 102:563-70.

36 Eggleston PA, Arruda LK. Ecology and elimination of cockroaches and allergens in the home. J Allergy Clin Immunol 2001; 107:S422-9.

37 Holgate ST. Mediator and cellular mechanisms in asthma. The Philip Ellman lecture 1990. J Roy Coll Phys Lond 1990; 24:304-12.

38 Laitinen LA, Laitinen A. Remodeling of asthmatic airways by glucocorticosteroids. J Allergy Clin Immunol 1996; 97:153-8.

39 Boulet LP, Chakir J, Dube J, Laprise C, Boutet M, Laviolette M. Airway inflammation and structural changes in airway hyperresponsiveness and asthma: an overview. Can Respir J 1998; 5:16-21.
40 Shah A, Church MK, Holgate ST. Tumour necrosis factor alpha: a potential mediator of asthma. Clin Exp Allergy 1995; 25:1038-44.

41 Kips JC, Tavernier JH, Joos GF, Peleman RA, Pauwels RA. The potential role of tumour necrosis factor alpha in asthma. Clin Exp Allergy 1993; 23:247-50.

42 Kanehiro A, Lahn M, Makela MJ et al. Tumor necrosis factoralpha negatively regulates airway hyperresponsiveness through gamma-delta T cells. Am J Respir Crit Care Med 2001; 164:2229-38.

43 Konno S, Gonokami Y, Kurokawa M et al. Cytokine concentrations in sputum of asthmatic patients. Int Arch Allergy Immunol 1996; 109:73-8.

44 Bradding P, Roberts JA, Britten KM et al. Interleukin-4, -5, and -6 and tumor necrosis factor-alpha in normal and asthmatic airways: evidence for the human mast cell as a source of these cytokines. Am Respir Cell Mol Biol 1994; 10:471-80.

45 Ackerman V, Marini M, Vittori E, Bellini A, Vassali G, Mattoli S. Detection of cytokines and their cell sources in bronchial biopsy specimens from asthmatic patients. Relationship to atopic status, symptoms, and level of airway hyperresponsiveness. Chest 1994; 105:687-96.

46 Stirling RG, Chung KF. Future treatments of allergic diseases and asthma. Br Med Bull 2000; 56:1037-53.

47 Azevedo I, de Blic J, Dumarey CH, Scheinmann P, Vargaftig BB, Bachelet M. Increased spontaneous release of tumour necrosis factor-alpha by alveolar macrophages from wheezy infants. Eur Respir J 1997; 10:1767-73.

48 Rudmann DG, Moore MW, Tepper JS et al. Modulation of allergic inflammation in mice deficient in TNF receptors. Am J Physiol Lung Cell Mol Physiol 2000; 279:L1047-57.

49 Broide DH, Stachnick G, Castaneda D, Nayar J, Sriramarao P. Inhibition of eosinophilic inflammation in allergen-challenged TNF receptor p55/p75 - and TNF receptor p55-deficient mice. Am J Respir Cell Mol Biol 2001; 24:304-11.

50 Hessel EM, Van Oosterhout AJ, Van Ark I et al. Development of airway hyperresponsiveness is dependent on interferon-gamma and independent of eosinophil infiltration. Am J Respir Cell Mol Biol 1997; 16:325-34.

51 Zuany-Amorim C, Haile S, Leduc D et al. Interleukin-10 inhibits antigen-induced cellular recruitment into the airways of sensitized mice. J Clin Invest 1995; 95:2644-51.

52 Renzetti LM, Paciorek PM, Tannu SA et al. Pharmacological evidence for tumor necrosis factor as a mediator of allergic inflammation in the airways. J Pharmacol Exp Ther 1996; 278:847-53.

53 Elliott MJ, Maini RN, Feldmann M et al. Treatment of rheumatoid arthritis with chimeric monoclonal antibodies to tumor necrosis factor alpha. Arthritis Rheum 1993; 36:1681-90.

54 Matheson JM, Lemus R, Lange RW, Karol MH, Luster MI. Role of tumor necrosis factor in toluene diisocyanate asthma. Am J Respir Cell Mol Biol 2002; 27:396-405.

55 Call DR, Nemzek JA, Ebong SJ, Bolgos GL, Newcomb DE, Remick DG. Ratio of local to systemic chemokine concentrations regulates neutrophil recruitment. Am J Pathol 2001; 158:715-21.

56 Remick DG, Green LB, Newcomb DE, Garg SJ, Bolgos GL, Call DR. CXC chemokine redundancy ensures local neutrophil recruitment during acute inflammation. Am J Pathol 2001; 159:1149-57. 
57 Bischoff SC, Sellge G, Lorentz A, Sebald W, Raab R, Manns MP. IL-4 enhances proliferation and mediator release in mature human mast cells. Proc Natl Acad Sci USA 1999; 96:8080-5.

58 Gonzalo JA, Lloyd CM, Kremer L et al. Eosinophil recruitment to the lung in a murine model of allergic inflammation. The role of T cells, chemokines, and adhesion receptors. J Clin Invest 1996; 98:2332-45.

59 Jose PJ, Griffiths-Johnson DA, Collins PD et al. Eotaxin: a potent eosinophil chemoattractant cytokine detected in a guinea pig model of allergic airways inflammation. J Exp Med 1994; 179:881-7.

60 Mattoli S, Stacey MA, Sun G, Bellini A, Marini M. Eotaxin expression and eosinophilic inflammation in asthma. Biochem Biophys Res Commun 1997; 236:299-301.

61 Garcia-Zepeda EA, Rothenberg ME, Ownbey RT, Celestin J, Leder $\mathrm{P}$, Luster AD. Human eotaxin is a specific chemoattractant for eosinophil cells and provides a new mechanism to explain tissue eosinophilia. Nat Med 1996; 2:449-56.

62 Wong CK, Zhang JP, Ip WK, Lam CW. Activation of p38 mitogenactivated protein kinase and nuclear factor-kappaB in tumour necrosis factor-induced eotaxin release of human eosinophils. Clin Exp Immunol 2002; 128:483-9.

63 Terada N, Hamano N, Nomura T et al. Interleukin-13 and tumour necrosis factor-alpha synergistically induce eotaxin production in human nasal fibroblasts. Clin Exp Allergy 2000; 30:348-55.
64 Sabatini F, Silvestri M, Sale R et al. Fibroblast-eosinophil interaction: modulation of adhesion molecules expression and chemokine release by human fetal lung fibroblasts in response to IL-4 and TNF-alpha. Immunol Lett 2002; 84:173-8.

65 Sato E, Nelson DK, Koyama S, Hoyt JC, Robbins RA. Inflammatory cytokines modulate eotaxin release by human lung fibroblast cell line. Exp Lung Res 2001; 27:173-83.

66 Pang L, Knox AJ. Regulation of TNF-alpha-induced eotaxin release from cultured human airway smooth muscle cells by beta2-agonists and corticosteroids. FASEB J 2001; 15:261-9.

67 Katayama H, Yokoyama A, Kohno N et al. Production of eosinophilic chemokines by normal pleural mesothelial cells [comment]. Am J Respir Cell Mol Biol 2002; 26:398-403.

68 Miyamasu M, Misaki Y, Yamaguchi M et al. Regulation of human eotaxin generation by Th1-/Th2-derived cytokines. Int Arch Allergy Immunol 2000; 122:54-8.

69 Holgate ST. Cytokine, anti-cytokine therapy for the treatment of asthma and allergic disease. Cytokine 2004; 28:152.

70 Bryan SA, Leckie MJ, Hansel TT, Barnes PJ. Novel therapy for asthma. Expert Opin Invest Drugs 2000; 9:25-42.

71 Feldman M, Taylor P, Paleolog E, Brennan FM, Maini RN. AntiTNF alpha therapy is useful in rheumatoid arthritis and Crohn's disease: analysis of the mechanism of action predicts utility in other diseases. Transplantation Proceedings 1998; 30:4126-7.

72 Taylor PC. Anti-TNF alpha therapy for rheumatoid arthritis: an update. Internal Med 2003; 42:15-20. 